\title{
The Silviculture Conference Multiple purpose silviculture in British Columbia
}

\author{
by Henry Benskin ${ }^{1}$ and Lorne Bedford ${ }^{2}$
}

\section{Introduction}

This paper was prepared for presentation to the 1993 Silviculture Conference held September 12-15 in Toronto, Ontario. Its primary purpose was to provide a regional report on silviculture in British Columbia to the Conference.

A few statistics about BC are provided for those who may not be familiar with the province. Major trends in $\mathrm{BC}$ silviculture are given as a follow-up to the presentation by the Director of the Ministry of Forests' Silviculture Branch to the 1991 Silviculture Conference.

The success of the basic silviculture program is reviewed. British Columbia is doing its basic job well but there are new challenges arising.

The Many Masters section identifies some of the many social objectives which silviculture programs must now meet. How BC is using silviculture to help meet some of the wide variety of demands is presented in the Serving the Masters section.

\section{A Few Definitions}

"Basic silviculture" in British Columbia consists of the harvesting and silviculture operations that are for the purpose of establishing a free growing crop of trees of a commercially valuable species.

"Incremental silviculture" means silviculture other than basic silviculture.

"Year", in this paper, can be either a calendar year or the first year of a fiscal year which spans two calendar years (e.g., province of BC fiscal year 91/92 data is referred to in the text and tables as 1991).

\section{About British Columbia}

About half of British Columbia is forest land (Figure 1). Only a little more than one-half of this, or about one-quarter of the province, is considered to be productive and available from a timber harvesting standpoint. However, the "non-productive" and "un-available" forest has many other uses - some of which may call for silviculture treatments as this paper illustrates.

British Columbia has about one-half of the national softwood inventory. About $60 \%$ of Canada's lumber and $30 \%$ of pulp exports come from BC.

Ninety-six percent of the forests are coniferous. In round numbers, 75 million cubic meters are annually harvested from about 200000 ha. Over $90 \%$ of the harvest in 1991 was by clearcutting.

Almost $20 \%$ of BC's employment is directly or indirectly attributable to the forest industry.

\footnotetext{
${ }^{1}$ Director, Silviculture Branch, British Columbia Forest Service, Victoria, British Columbia, Canada.

${ }^{2}$ Forest Establishment Officer, Silviculture Branch, British Columbia Forest Service, Victoria, British Columbia, Canada.

Prepared for The Silviculture Conference, September 12, 1993, Toronto, Ontario.
}

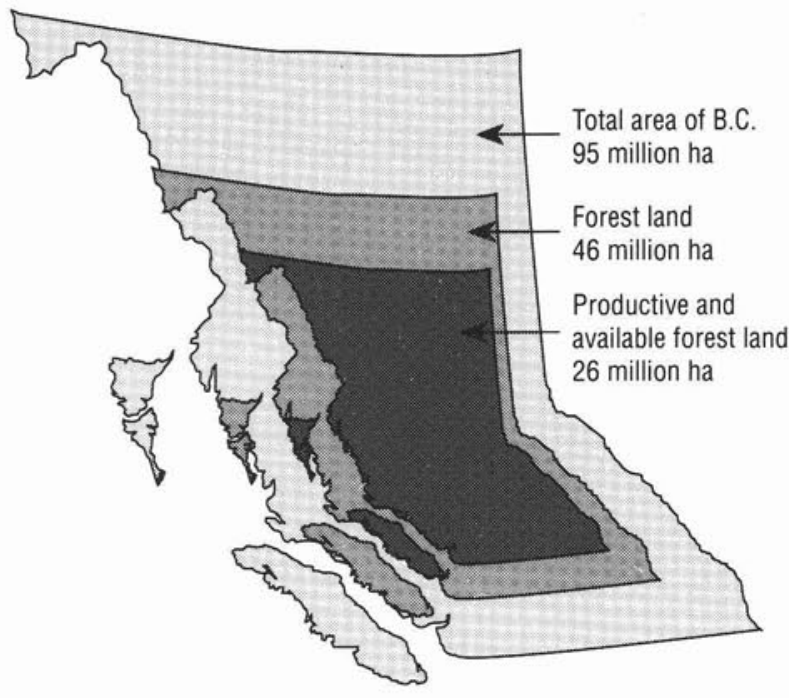

Figure 1. Slightly more than one quarter of the area of British Columbia is considered forest land available for harvesting.

\section{Major Trends in BC Silviculture}

The government essentially "privatized" basic silviculture in 1987 . In December of that year the Forest Act was amended to require basic silviculture on all areas harvested on or after October 1, 1987 and that it be done in accordance with a PreHarvest Silviculture Prescription, or PHSP.

A high degree of importance is placed on the PHSP. It defines the reforestation objectives before harvesting and details the means to accomplish them.

It is this monumental change in the law that is responsible for many of the trends that follow.

\section{Trees Planted}

The planting program peaked in 1990 at 245 million trees (Figure 2). The downtrend since then is expected to stabilize somewhere between 175 and 200 million trees, depending on the area harvested from year to year.

Trees planted by the ministry peaked in 1989 at 73 million seedlings. In 1992 this fell to an estimated 47 million seedlings, about two-thirds that of the peak year. In the future much of what the ministry plants will be to meet the reforestation obligations of the small business program which now comprises over $12 \%$ of the provincial allowable annual cut (AAC). An increase in small business planting to 29 million seedlings will bring the ministry planting program back up to over 60 million seedlings in 1993.

The forest industry has always had a very strong involvement in the delivery of the planting program. However, after 1987 more and more of the trees that industry plants are paid for and planted at its expense. Reforestation of areas harvested by industry before 1987 is paid for by the province but is delivered by the companies. 
Trees (millions)

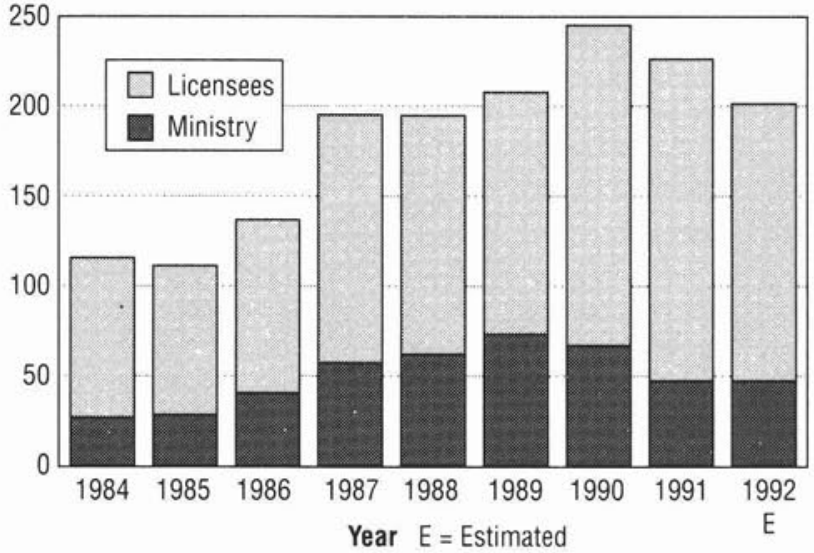

Figure 2. The number of trees planted peaked in 1990. Since 1987 industry must pay for planting trees on areas it harvests.

\section{Species Planted}

There has been a reduction in logging in spruce forests and an increase in logging in pine in the interior. This has contributed to more pine and less spruce being planted. Pine increased from $22 \%$ of the total in 1984 to $36 \%$ in 1991. (Figure 3). Another factor in the increase in pine is that on sites where both pine and other species are acceptable, pine is usually easier to get to free growing. Pine seedlings are also $10-15 \%$ cheaper than spruce.

The proportion of Douglas-fir being planted has changed dramatically, dropping from $14 \%$ in 1984 to $6 \%$ in 1991 . This can partially be attributed to much of the logging on the coast now being in higher elevations and also towards the west coast of Vancouver Island where hemlock and cedar forests predominate.

Based on tree species sown in the nurseries in 1993, these trends can be expected to continue for the next several years. Pine continues to increase and spruce decrease. Lodgepole pine alone comprised $41 \%$ of the total seedlings sown in 1993.

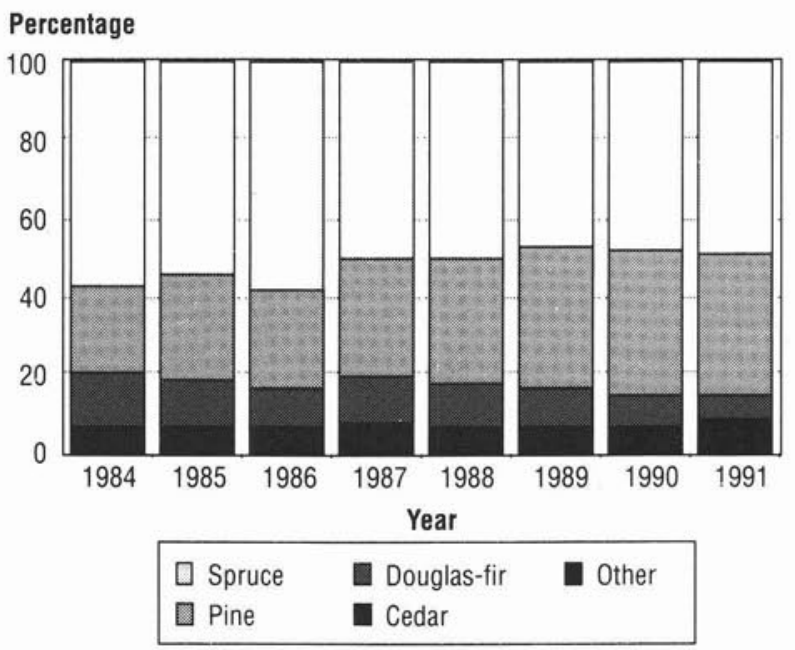

Figure 3. There has been a gradual increase in the proportion of pine seedlings planted while spruce and Douglas-fir have decreased.

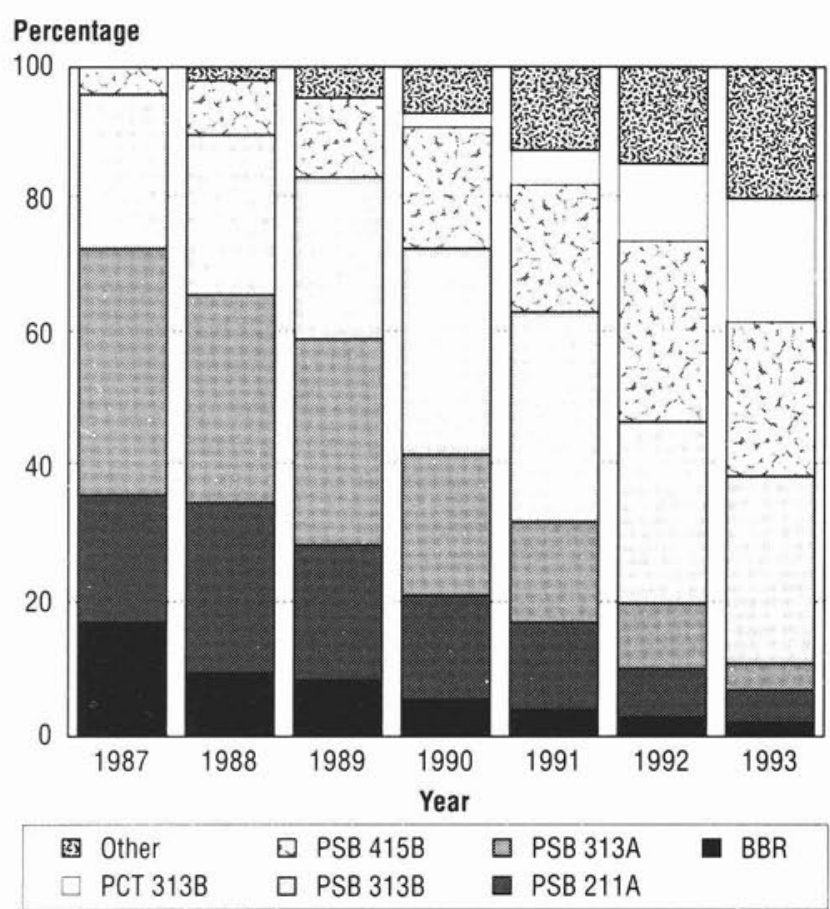

Figure 4. A-sized styroblocks have given way to B-sized blocks. Many more stock types are now in use.

\section{Stock Types}

There have been enormous changes in planting stock. Bareroot, and 211A and 313A styroblocks have fallen from comprising over $70 \%$ of total stock sown in 1987 to below $12 \%$ in 1993 (Figure 4).

The "new kids on the block" are the larger stock types, particularly the B- sized styroblocks which have fewer cavities per block in order to give a greater inter-tree spacing. Copper treated styroblocks for lodgepole pine have also become very popular in the past three years.

There is a significant increase in the variety of stock types available. The 9 stock types in use in 1987 have risen to 35 in 1993. At the same time there has been a trend away from twoyear old to one-year old container stock.

\section{Site Preparation}

The trends in site preparation that were noted at the 1991 Silviculture Conference are continuing. Figure 5 is an updated chart showing the strong move away from broadcast burning to mechanical site preparation. In 1991, over 99000 ha were treated mechanically while 41600 ha were treated using fire, either with broadcast or spot burning. The area on which fire was used is significantly reduced from 95500 ha in 1987, just four years before.

A wide variety of mechanical site preparation equipment is now available and the choice of tool to be used depends upon treatment objectives, costs, and site conditions. Excavators and disc trenchers currently dominate mechanical site preparation in BC.

\section{Spacing and Brushing}

The total area treated by spacing and brushing has increased by approximately $500 \%$ since 1982 (Figure 6). A dramatic rise 

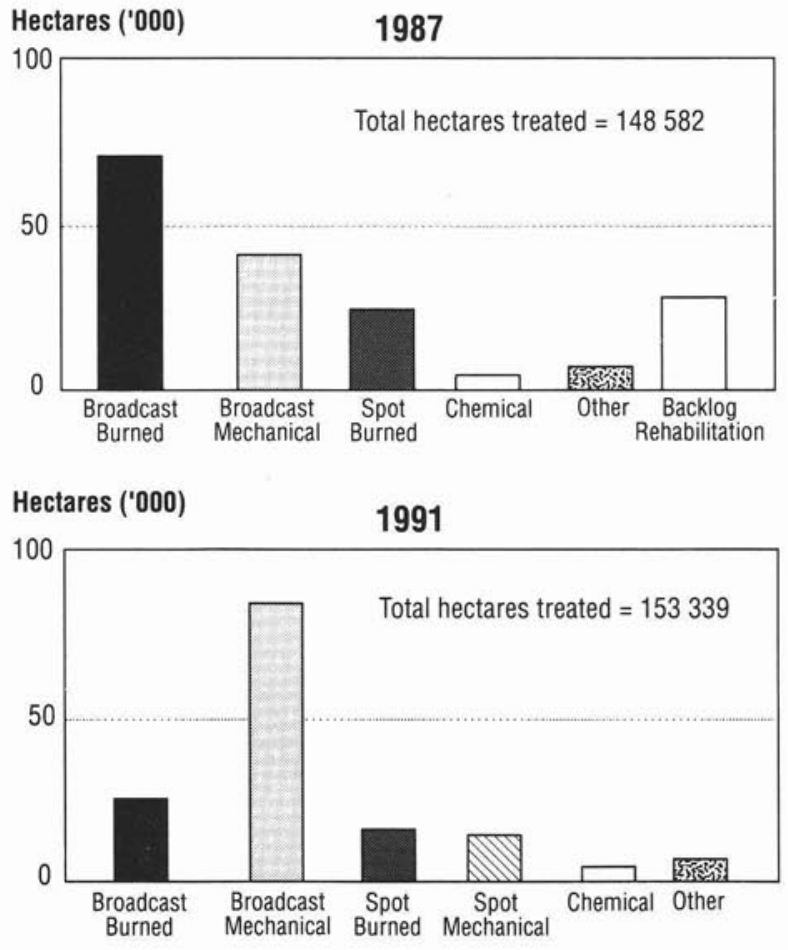

Note: Backlog rehabilitation not broken out for 1991.

Figure 5. Area burned has decreased while mechanical treatment has increased dramatically in recent years.

in spacing occurred in 1991 when FRDA II kicked in. Preliminary figures indicate approximately 38000 ha were spaced in 1992. In 1993 the program will be about 45000 ha.

Brushing peaked in 1989 and has tapered off since then. This can be partially attributed to the reduction in backlog NSR but is also due to better prescriptions. Often larger stock will be prescribed, or better site preparation will enable foresters to get a jump on the brush competition.

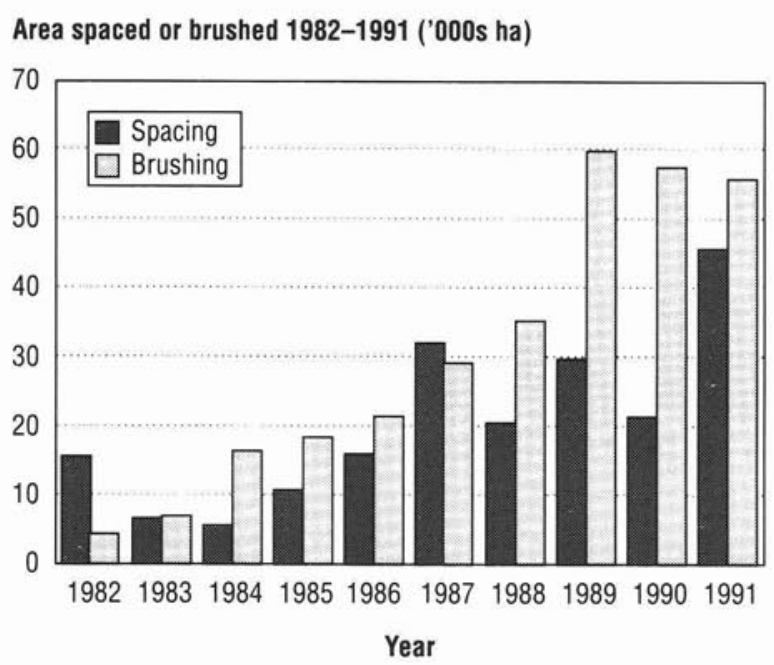

Figure 6. The total area treated by spacing and brushing has increased by approximately 500 per cent during the 10 -year period, 1982-1991.

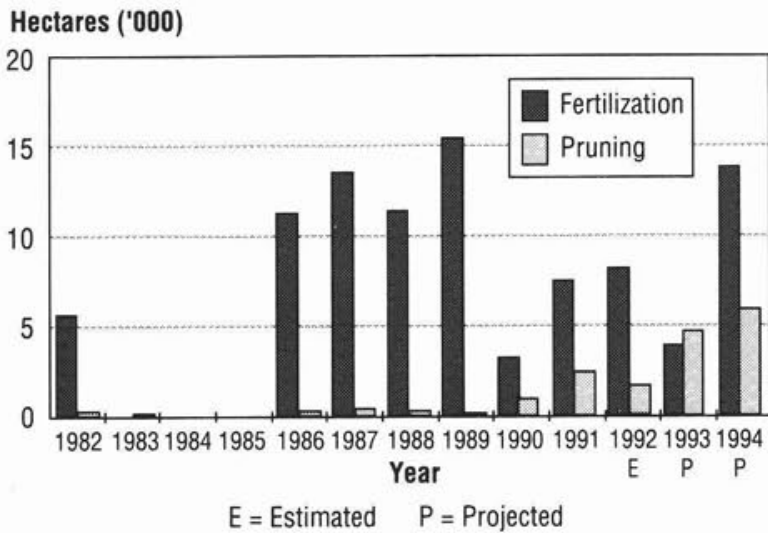

Figure 7. Fertilization and pruning are expected to increase over the next several years.

\section{Pruning and Fertilization}

Brushing and spacing are necessary to ensure free-growing crops of new trees. As such they are essential to basic silviculture. Pruning and fertilization, on the other hand, are used to improve the value of a stand. Because of this they are subject to the funding constraints of the federal and provincial governments. Most of the funding for these activities over the past ten years has come from cost-shared federal-provincial forestry agreements (IFMSA, FRDA I, FRDA II). Figure 7 shows that there was no funding for fertilization from 1983 to 1985 and that it suffered again in 1990 when we were between FRDA's.

Very little pruning took place until recently (Figure 7). Over 2600 ha was pruned in 1991 . The 1993 goal is 4900 ha and it is expected to rise to 9000 ha in 1997 , subject to funding. Strategic studies have indicated that we should be doing more pruning to increase the value of our timber.

\section{Basic Silviculture is Well in Hand... To a Point}

Basic silviculture is now well in hand in BC... to a point, that is... there are new challenges on the horizon.

\section{Seedling Survival}

The trees being planted are surviving much better than they used to. Figure 8 shows that average seedling survival for all species and stock types has increased from a dismal 54\% in 1982 to a very respectable $87 \%$ in 1990 . We owe this not only

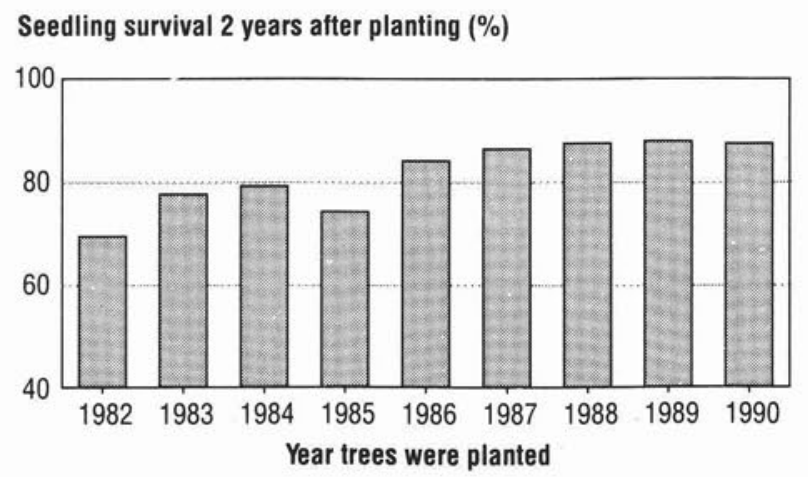

Figure 8. Average seedling survival for all species and stock types has increased from $54 \%$ in 1982 to $87 \%$ in 1990 . 


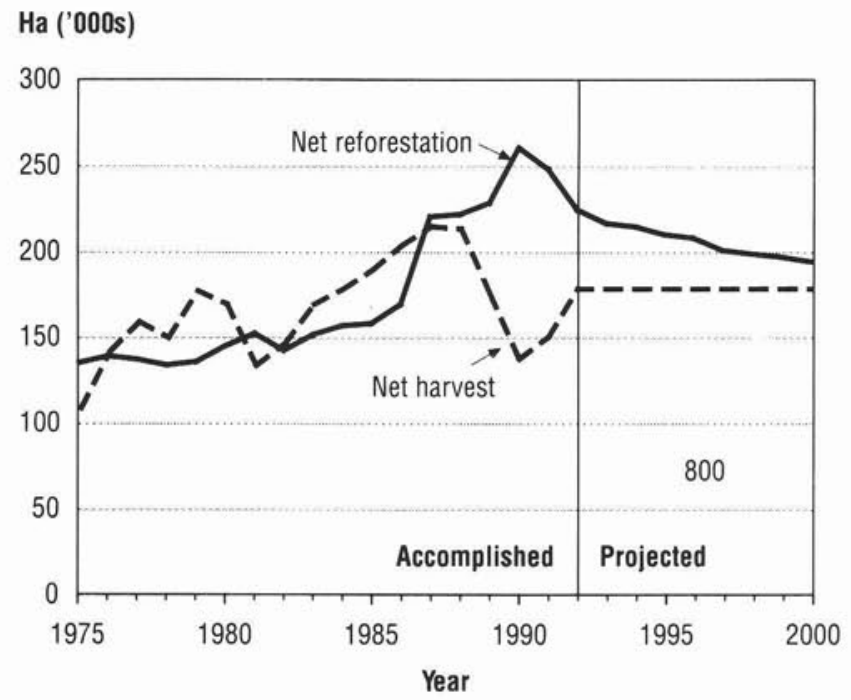

Figure 9. More area has been reforested than harvested in $\mathrm{BC}$ each year since 1987.

to better prescriptions under the PHSP but also to the tremendous improvement in our knowledge through research, a lot of which was conducted under FRDA.

\section{Net Area Reforested}

More area has been reforested than harvested every year since 1987 (Figure 9). This situation is expected to continue for some time into the future.

\section{Backlog NSR Reduced}

High survival combined with the fact that more area is being reforested annually than is being harvested translates into a reduction in backlog NSR, as illustrated by Figure 10 .

Backlog NSR is defined in British Columbia as that area not satisfactorily restocked within acceptable time periods on good and medium site managed forest land denuded prior to

\section{Backlog NSR ('000s ha)}

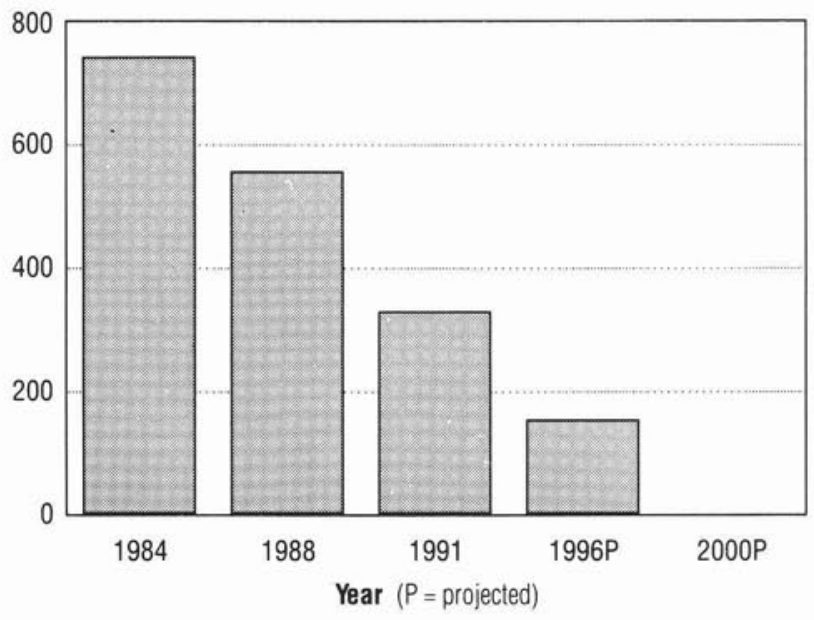

Figure 10. Backlog NSR has decreased from 738000 ha in 1984 to 327000 ha in 1991 . The goal is to eliminate all backlog NSR by the year 2000.
1982 and that is accessible and economically viable to treat. This Backlog NSR was a specific target of FRDA I, which expired in 1990. Since then the province has made a commitment to continue funding until this backlog is wiped out by the year 2000 . It has been reduced by more than $50 \%$ since 1984 .

To complete the picture, basic silviculture on areas logged between 1982 and 1987 is funded by the province. After September 30,1987 it is funded by either the licensee or by the ministry's small business program.

\section{Audit Program}

Basic silviculture performance is monitored through the audit program.

Figure 11 illustrates two things. First, the area audited has been increasing in response to more area that's "in progress" towards free growing. By law, all areas harvested since 1987 must be regenerated. Those areas not meeting the standards must be corrected or licensees face penalties. Secondly, the lowest projected success rate has been 94 per cent, with results consistently being in the 97 to 98 per cent range.

In addition to the field audits shown in Figure 11, the ministry recently undertook a province-wide review of the PHSP process. The review examined documents relating to a total of 36000 blocks harvested between October 1, 1987 and September 30,1992 . It found that $97 \%$ of the areas had a PHSP in place. A sampling of those blocks which did not have PHSP's indicated that basic silviculture was being carried out on $92 \%$ of the areas. As a result of this audit the ministry has taken steps to tighten administrative procedures surrounding the PHSP process and to ensure that appropriate treatment occurs on those areas identified as falling short of requirements. Many of the identified problems occurred in the early transitional period right after the new legislation was enacted in 1987.

\section{Many Masters: Defining Social Objectives}

In the "good ol' days" silviculture was pretty straight forward. There were two simple facts of life for foresters: one, silviculture

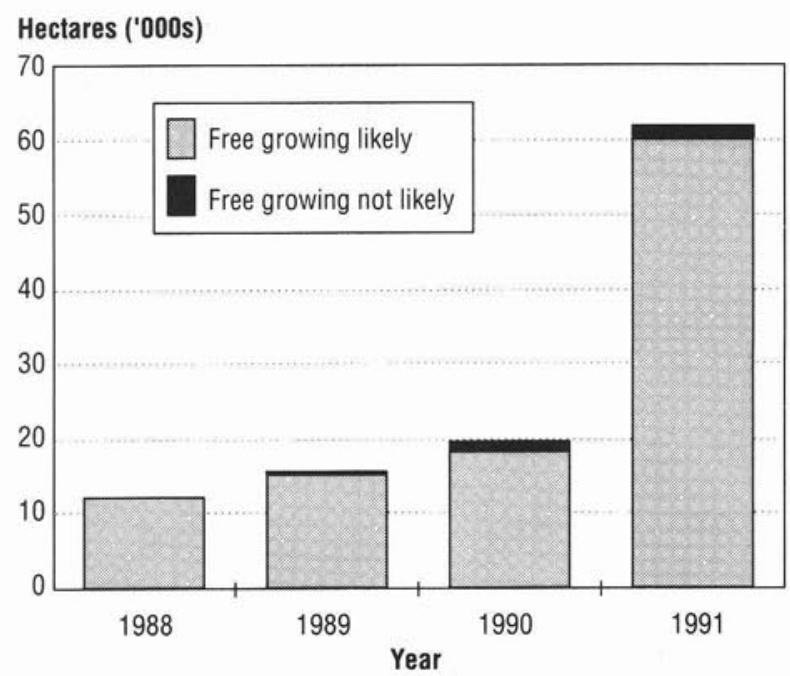

Figure 11. The number of audits is increasing in response to a larger area with basic silviculture in progress. Projected success rates are consistently in the high 90 percentile range. 
was almost exclusively concerned with getting successful regeneration after logging, and two; it wasn't working, or there wasn't enough of it going on. Backlog NSR was increasing. Now, in the 1990 's, life for the forester is not nearly so simple.

The public has many demands about how forests should be managed and for what. Defining these social objectives is a difficult task. Forestry must now serve "many masters". While it is the job of politicians to sort the major uses to which our land will be devoted, it is up to foresters to provide the scientific know-how, to help in maximizing the benefits that come from a finite resource, and to respond to the public's concern about forest practices.

In the Brundtland report, Our Common Future, there is much discussion about the environment and the economy. Both of these are of vital importance to British Columbia and its citizens. The major issues appear to be, on the environment side:

- Global Health;

- Gentler Forest Practices; and

- Managing for all Forest Values.

On the economy side they are:

- Timber Supply;

- Other Forest-Dependent Industries, e.g., tourism; and

- Employment

\section{Global Health}

Among other global health issues, people are worried about carbon dioxide concentrations and global warming. The jury is still out but the potential consequences are scary - rising ocean levels, forest fires, movement in tree species ranges, and so on. It has been proposed that forests have a role to play as "carbon sinks" by taking carbon out of the air. The forests of British Columbia constitute $7 \%$ of the world's softwood growing stock. They are very significant to the matter of global health.

\section{Gentler Forest Practices}

The anti-clearcut movement, visual quality concerns, and protests about the use of chemicals in forests are linked to a greater awareness of, and concern for the environment. Environmentalists want forest managers to be more gentle with "mother earth" by being less invasive in our forest practices. To many people not familiar with forestry practice a clearcut is

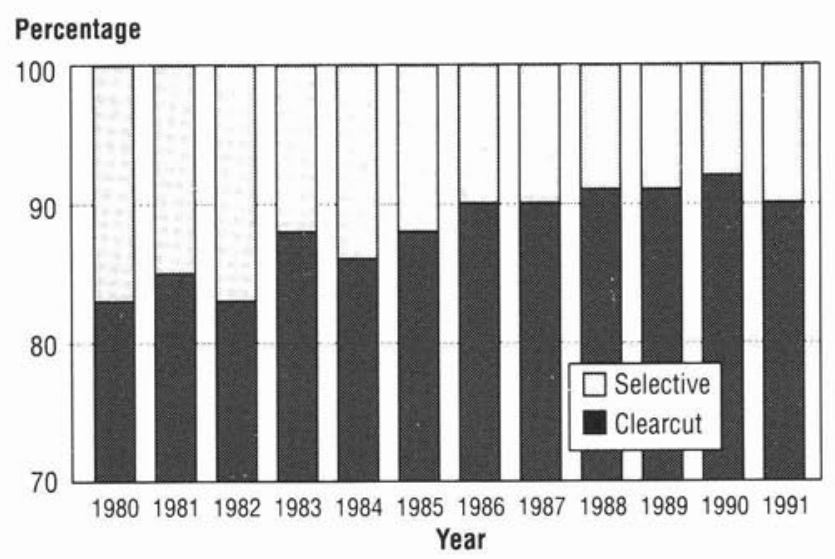

Figure 12. The proportion of area clearcut in $\mathrm{BC}$ has risen over the past decade from below $85 \%$ to over $90 \%$. This trend may be reversing with a reduction in area clearcut in 1991 from the year before. nothing other than brutal treatment of the land. Selective harvesting is seen as being more gentle, creating, in some people's eyes, less change. Certainly it is better visually.

As shown in Figure 12 the proportion of area clearcut in $\mathrm{BC}$ has risen over the last decade from below $85 \%$ to over $90 \%$ of the total area harvested. Later on, we'll see how the ministry is attempting to reverse this trend through the Silviculture Systems Program. Indeed, the trend may already be reversing, as the proportion of area clearcut in 1991 was slightly less than that in 1990.

\section{Managing for All Values}

Silviculture used to be a simple task - grow trees for the next crop. Not any more! Now there is the challenge of managing for many more values. Not only traditional ones such as fish and wildlife but relatively new ones like biological diversity and old growth forests.

In the past, forest planning has usually been of the approach: How do we get the logs out without harming the other resources? How soon will it be before it becomes: How can we get the logs out in concert with managing the other resources or resource values? Some of this is happening now, but try to imagine this question in the context of managing with equal emphasis for ten or even fifteen values all on the same piece of land. Silviculture will become an ever larger player in the result.

\section{Timber Supply}

The forest industry is by far the largest economic engine of the province and it will remain so for the foreseeable future. However, AAC's are falling and are anticipated to fall further (see Figure 13).

AAC's are also falling heavily in the U.S. Pacific Northwest. Will the surge in lumber prices in 1993 be indicative of future prices? Will there be a supply shortage pushing up prices? Will a sustained higher price for timber justify previously uneconomic silviculture activities?

Without a doubt silviculture has a significant potential role to play not only in timber supply but also in timber value. Recent strategic planning initiatives by the Silviculture Branch have been attempting to define this role.

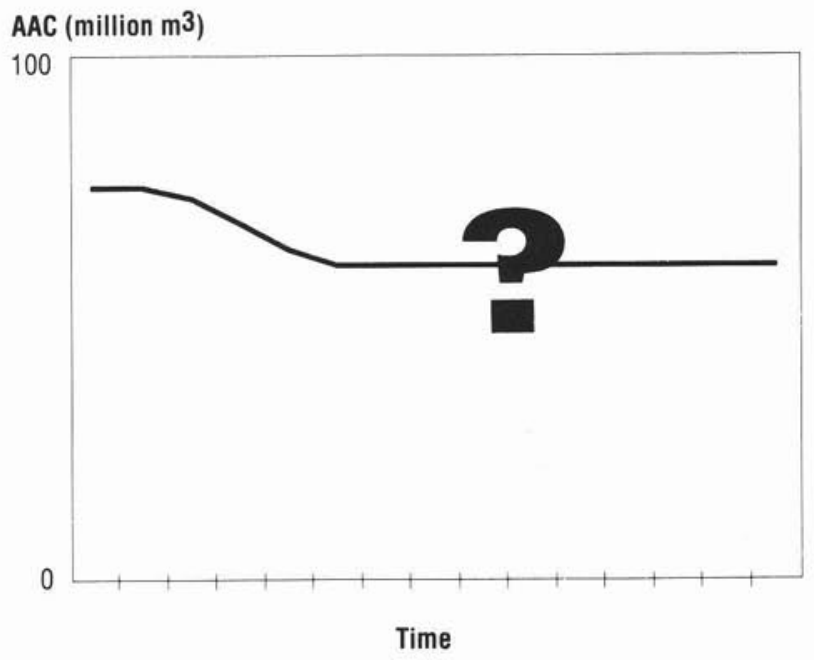

Figure 13. Allowable Annual Cuts are falling and are projected to fall further. 


\section{Other Forest-dependent Industries}

Although the forest industry will remain in the economic forefront for the foreseeable future, other forest-dependent industries are growing in importance.

Tourism, for example, is founded on the theme "Beautiful British Columbia." Tourists expect BC to live up to that image. There is a whole new tourism industry, eco-tourism, springing up out of the environmental movement. In 1991 tourism revenue was a significant $\$ 5.5$ billion (approximately $20 \%$ of which is businessrelated expenditure) compared to $\$ 10.2$ billion in forest products shipments (Figure 14.) .

A recent study undertaken by the Ministry of Forests identified 175 non-tree products, including such items as medicinal plants, fruits and berries, landscaping plants and craft products. While these may not compare economically with industries such as forestry and tourism, a great many of them can be influenced by silviculture regimes. Will we be conducting silviculture techniques to benefit growing mushrooms in the forest? It's a $\$ 35$ million industry in the State of Oregon and is already a multi-million dollar industry in BC.

\section{Employment}

Not only do the forests directly employ $6.5 \%$ of the $\mathrm{BC}$ workforce in the logging and processing industries, these are also among the highest paying jobs in the province, second only to those of the mining industry. When indirect employment is included, the forest industries are the source of livelihood for almost $20 \%$ of the provincial labour force.

The Forest Resources Commission found that over 200 communities in British Columbia are primarily dependent upon the forest industry. Another study found that one in five jobs in Greater Vancouver could be directly or indirectly attributable to the forest industry.

Silviculture is very labour intensive and has a lot of potential for employment creation.

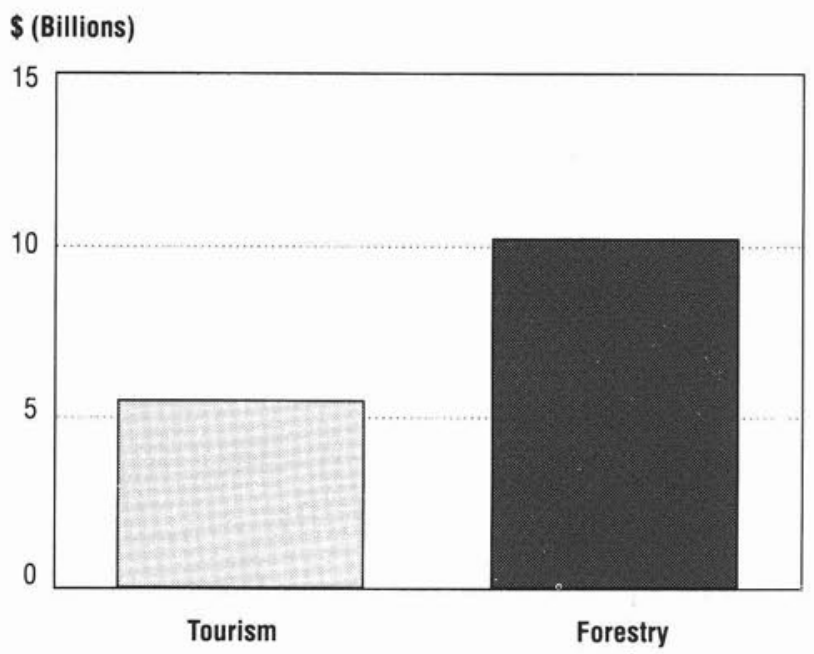

Figure 14. Tourism revenues are slightly over one-half the value of total forest products shipped in 1991 .

\section{Serving the Masters: Silviculture for Multiple Purposes}

So now that we know who the masters are, how are we going about serving them? Contrary to the images of monocultures, biological deserts, and deforestation that some would like to portray, there is an incredible amount of change going on in $\mathrm{BC}$ forest management. Silviculture is central to many of these.

The following $\mathrm{BC}$ initiatives are grouped under three basic objectives for silviculture:

- Basic Stewardship of all Values

- Investments to Improve Volume \& Value

- Employment

\section{Objective: Basic Stewardship of all Values}

In order to improve stewardship of all values, the Ministry of Forests has developed new guidelines in a number of areas, is experimenting with and implementing new silviculture and harvesting techniques, and is undertaking research and demonstration towards addressing the silviculture systems challenge.

\section{New Guidelines}

Biodiversity guidelines for all of $\mathrm{BC}$ are targeted for adoption by December, 1994. Draft guidelines for the coast were released in December, 1992 and are expected for the interior early in 1994. Some aspects of these guidelines will be reinforced by the coming Forest Practices Code. The guidelines address biodiversity at both the landscape and the stand level. Stand management guidelines cover silviculture systems, harvesting, regeneration, stand tending and pest management.

Soil conservation guidelines for harvesting in the interior were released in May 1993. These guidelines define what constitutes detrimental soil disturbance and places limits on acceptable amounts.

Interim guidelines for mechanical site preparation are in place and are expected to be finalized in 1994. These guidelines place restrictions on detrimental and total site disturbance.

In 1992 the Ministry of Forests signed a memorandum of understanding with the Ministry of Environment, Lands and Parks, and the Worker's Compensation Board concerning wildlife and danger trees. This memorandum ensures that forestry operations provide for the retention of wildlife trees to maintain habitat for species dependent upon them, while at the same time ensures worker safety will not be compromised. Wildlife/danger tree assessments are to be undertaken at the PHSP stage and incorporated into development plans. For incremental silviculture activities they are done during the pre-stand tending survey.

\section{New Silviculture Techniques}

New silviculture techniques are being implemented in the areas of vegetation management, spacing and mechanical site preparation.

In vegetation management, the use of chemicals in the forest is being minimized through better site preparation, better planting stock, sheep browsing and improving on forage/seedling management. Chemically treated area has dropped from 58000 ha in 1990 to 35000 ha in 1991. In 1991, 4000 ha of brushing and site preparation was done by sheep. Sheep browsing is expected to keep increasing over the next few years. In 1993 it may top 10000 ha.

The sheep solution cannot be universally applied, however. Concern is growing over the potential effect on domestic water supplies and over the interactions between sheep and other wildlife species. 
It was noted earlier that the biodiversity guidelines cover stand tending. The spacing component promotes, among other things: retention of snags, and of some dying green trees that are likely to become snags; variable stand density; and mixed-species stands.

Overstocking is seen to be just as detrimental to achieving an acceptable free growing crop of trees as is understocking. Consequently, the Silviculture Regulation provides for the setting of maximum density guidelines. Provincially correlated standards were issued in 1990 for lodgepole pine and in 1993 for drybelt fir.

One of the big reasons behind the fantastic improvement in survival is greatly improved site preparation. There is now a good understanding of how to overcome soil temperature and moisture problems through site preparation. The Ministry of Forests has done extensive work in researching and developing site preparation equipment, particularly related to soil mounding.

\section{The Silviculture Systems Challenge}

Historically, the standard prescription has been: clearcut... burn... plant. However, a lot less area is now being burnt and there are significant changes in species and stock types being planted. Now, what's needed is a hard look at clearcutting practices. This is being done through the Silvicultural Systems Program. Since its inception in 1990 , approximately $\$ 4.6$ million has been spent across the province on research and demonstration for partial cutting systems. Another $\$ 1.7$ million is being spent in 1993. As of March, 1993, over 75 projects were underway or have been completed. Following are several of these initiatives.

Advanced Regeneration. One modification is to take a closer look at protecting and utilizing the advanced regeneration in many stands. In the interior, spruce often comes up under pine on the slightly wetter sites, and on the coast balsam will often come up under other species.

Selection Systems. The range of effects of alternative silviculture systems is enormous. Current studies are examining the many aspects of selection systems. For example, related to wildlife there are studies on wildlife diversity, breeding habitats, caribou habitat, and grizzly bear habitat. For forest management, there are studies on visual quality, seedling shade tolerance, root rot incidence, pine beetle hazard reduction, dry sites, windthrow, biodiversity, and steep slopes. And on the economic side of things, studies are looking at impacts on wood supply, growth and yield, and costs. This is just a partial list!

Mixed Hardwood/Softwood Stands. In the northeast corner of BC, on the eastern side of the Rocky Mountains, lies the Peace River region where hardwoods like to grow just as much as softwoods. In the past, these mixed forests were not a problem to manage because nobody really wanted them. Now, with aspen becoming an economic species there are some real challenges with regeneration, not the least of which is to decide which type of regenerated forest is desired. Do we target to grow back hardwoods or softwoods exclusive of each other? Or, do we allow nature to take its course and manage for mixed stands? Is partial cutting a viable silviculture regime in these stands? There are lots of questions that the ministry is working on finding the answers to.

New Forestry. In 1991 the Old Growth Strategy Project commissioned a guide for British Columbians on the Principles and Practices of
New Forestry. In New Forestry, timber is seen as a by-product of forests which have sustaining biological diversity and long-term ecosystem health as their primary functions. A research and demonstration project is being carried out in an effort to explore some of these new concepts.

Commercial Thinning. Silviculture is also expanding in the area of enhancing and protecting short term wood supply. In 1993, commercial thinning will take place on approximately 1000 ha. While this program is relatively small at present, its importance is increasing.

\section{Objective: Improving Volume and Value}

Efforts are being directed towards improving the volume and value of $\mathrm{BC}$ 's forests along several fronts.

Objective: Investment to Improve Volume and Value

- Strategic Planning

- Forest Health

- Incremental Silviculture

- Incentives for Investment

\section{Strategic Planning}

Emphasis on strategic planning is increasing. Through a consulting contract the ministry has recently completed a world review of strategic silviculture planning processes for potential application to British Columbia. What the consultants found was that strategic planning processes in many other jurisdictions were pointing to an increasing emphasis on growing quality sawlogs; that quality will command premium prices in the future. But they also noted that BC shouldn't put all its eggs in one basket.

With the same consulting firm the ministry has been taking the first steps towards developing a decision support system to evaluate the implications of alternative silvicultural strategies on timber supply at the forest level.

\section{Forest Health}

A significant strategic organization move has been the recent transfer of the Forest Health Section from Protection Branch to Silviculture Branch. This move recognizes that the management of insects and disease is integral to silvicultural systems.

The ministry is spending about $\$ 10.5$ million on forest health treatments in 1993.

\section{Incremental Silviculture}

Strategic planning points to value added timber. In keeping with this the trend has been towards more spacing, fertilization and pruning. The big questions now are: how much? and where?

There is now quite a lot of knowledge about spacing for maximum density and about what stands respond to fertilization. However, there is still lots to learn about pruning and commercial thinning. There does not yet appear to be any definitive answer as to how to get more volume from our forests to offset the anticipated further harvest reduction.

\section{Incentives for Investment}

Ways need to be found to encourage the industry to invest in the forest. Methods to date have not worked. There is also a need to look at whether such investments will be at cross-purposes with other possible objectives such as biodiversity and new forestry. 


\section{Objective: Employment}

As a relatively young industry silviculture offers many new employment opportunities. There is a constant demand for skilled workers that the government is helping to fill through special employment programs.

\section{Employment from Silviculture}

Silviculture is a highly labour-intensive industry, generating an estimated four to six thousand person-years of direct employment annually in British Columbia.

\section{Employment for First Nations Peoples}

The province is working with First Nations peoples to encourage and develop silviculture contracting expertise and to provide employment. In 1991, the ministry began a pilot project to directly award silviculture contracts up to $\$ 50,000$ to First Nations peoples. The goal is to develop sufficient expertise to enable First Nations contractors to become competitive participants in the silviculture industry.

\section{Forest Worker Development Program}

There's been FWAP, FORSAR, COMFOR and FEP. Now there is FWDP, the Forest Worker Development Program. A total of $\$ 39$ million is being invested in 1993. The objectives are to:

- create employment and assist employment-disadvantaged groups;

- promote economic recovery in non-metropolitan areas where the recession has had a significant effect on employment; and

- encourage a localized forest contracting industry.

The FWDP has a three-tiered structure: workers will progress from an Entry Level, where they learn basic skills, through the Bridging Level, where production skills are acquired, and on to the Local Contracting Level, where workers become integrated into the workforce.

\section{Summary}

- Forecasted trends are continuing

- Basic silviculture is well in hand

- Silviculture must serve many new social objectives

- Silviculture challenges are being met on many fronts

\section{Forecasted Trends}

There have been major shifts in silviculture trends over the past few years, primarily resulting from the "privatization" of basic silviculture in 1987, but also in response to social objectives.

The total number of trees planted annually is decreasing as a result of reducing demand and there are significant changes in species and stock types being used.

There is substantially less broadcast burning and more mechanical site preparation taking place. The use of chemicals in brushing is giving way to alternate techniques such as manual treatments and sheep browsing. Better prescriptions are avoiding the necessity for brushing altogether. Stand tending and incremental silviculture are increasing.

\section{Basic Silviculture is Well in Hand}

Basic silviculture is well in hand: seedling survival has increased dramatically, the area being reforested has been greater than the area harvested since 1987, and backlog NSR is being eliminated. Audits indicate we can expect a high degree of success in achieving free growing crops after timber harvesting.

Social Objectives Must be Served

There is a growing demand to use silviculture for meeting social objectives for values other than timber. The public is concerned about global health and wants different forest practices. BC, having $7 \%$ of the world's softwood growing stock, has an important role to play.

\section{Silviculture is Moving to Meet the Challenges}

$\mathrm{BC}$ is moving to meet the silviculture challenges in many ways. New guidelines have recently been developed to govern forest practices and a forest practices code will be in place in 1994. New silviculture techniques are being used that are not only more successful but help to meet the social objectives discussed. A substantial research and demonstration program has been launched to develop alternatives to clearcutting.

\section{Acknowledgements}

The assistance of Mr. Larry Atherton of L.P. Atherton \& Associates in the preparation of this paper is gratefully acknowledged. 